\title{
The Past, the Present, and a Very Bright Future
}

Glen J Pearson

Yesterday is gone. Tomorrow has not yet come. We have only today. Let us begin. - Mother Teresa

$\mathrm{T}$ The history of pharmacy dates back 400 years in Canada, to the arrival in Quebec City, on July 15, 1617, of Louis Hébert, revered as the first Canadian apothecary. It took a few more centuries before the specialty of hospital pharmacy emerged, but today nearly $17 \%$ of all registered pharmacists in Canada strive to maintain and improve the medication management and pharmaceutical care of patients in hospital settings. The Canadian Society of Hospital Pharmacists (CSHP) has been supporting the advancement of hospital pharmacy practice and achievement of the highest standards for nearly 75 years (CSHP milestones: https:// www.cshp.ca/our-history).

Today, CSHP staff and volunteers work diligently to ensure that hospital pharmacists are positioned to practise to their full scope in collaborative settings and to create a stronger health care system, with the ultimate goal of optimizing patients' health. Over the past year, we have both initiated and responded to requests for consultations involving Health Canada and other pharmacy and medical professional groups on topics important to our profession. In late 2016, for example, I had the opportunity to offer the expertise and perspective of hospital pharmacists to the Citizens' Reference Panel on Pharmacare in Canada. This initiative was designed to constructively inform the debate about the future of public funding for prescription medicines. The Panel's recommendations concerning implementation of a national pharmacare system were shared with the federal Minister of Health and her provincial counterparts (https://open.library.ubc.ca/ cIRcle/collections/facultyresearchandpublications/52383/items/ 1.0340089). Subsequently, CSHP consulted members and updated its position statement on this topic.

After nearly 7 years of work with the Office of Controlled Substances, CSHP was excited in March 2017 when Health Canada issued a class exemption to section 56 of the Controlled Drugs and Substances Act for practitioners prescribing methadone to inpatients in a hospital setting. This means that practitioners are no longer required to obtain a temporary exemption to continue treating hospital inpatients who were taking methadone before their admission. For details, see the Health Canada website (www.hc-sc.gc.ca/hc-ps/substancontrol/pol/pol-docs/ methadoneexemption-methadone-eng.php).

\begin{abstract}
More recently, CSHP has been engaged in numerous initiatives related to the opioid crisis. In collaboration with the federal Minister of Health, CSHP has committed to the Joint Statement of Action to Address the National Opioid Crisis (https://www.canada.ca/en/ health-canada/services/
\end{abstract} substanceabuse/opioid-

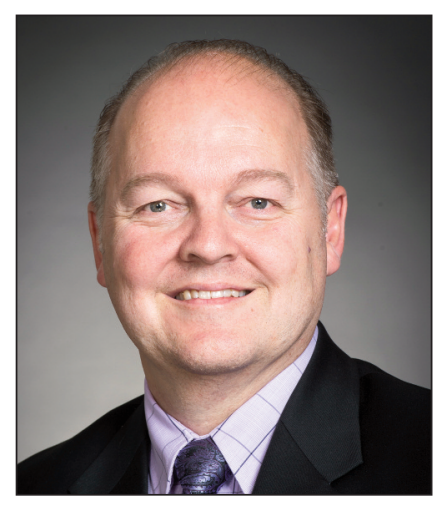
conference/joint-statement-action-address-opioid-crisis.html). Further to this goal, we participated with the Federal Health Minister in a roundtable on the opioid crisis, hosted by HealthCare $C A N$ on June 12, 2017 during the National Health Leadership Conference in Vancouver. Participants shared their insights about and experiences of best practices related to the prevention, harm reduction, and the management of addiction.

As I begin to wind down my 3-year Presidential term with CSHP, I find myself reflecting on my own experience and CSHP's accomplishments during this time. I am grateful to have had the opportunity to be part of the leadership of this organization and to have worked with so many outstanding leaders in hospital pharmacy. I am honoured and remain excited to be a member of this wonderful profession. We have advanced so far over the past few years, but the journey continues - there are always new challenges to conquer. Our future looks bright, and CSHP will most certainly be a major part of the continued advancement of hospital pharmacy. Make sure that you are engaged and support CSHP in these efforts.

Being fully present is the best guarantee for a bright future.
-Guy Finley

Glen J Pearson, BSC, BScPhm, PharmD, FCSHP, FCCS, is Past President and External Liaison for the Canadian Society of Hospital Pharmacists. 